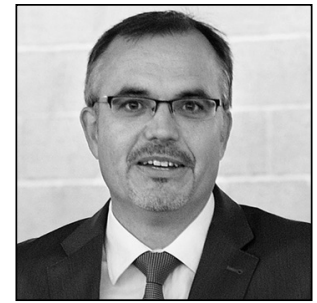

Henning Rosenau

Professor, Dr.

Martin Luther University of Halle-Wittenberg

\title{
The Human Right of Reproduction: Ovum Donation and Surrogacy
}

\section{Introduction}

In Germany, reproductive medicine is also a topic of discussion in the jurisprudential field. Debates rage about issues from the legal status of embryos to detailed questions such as whether the German Embryo Protection Act (ESchG) allows more than only three ova (human eggs) to be fertilised in vitro. However, the central questions about bioethics ${ }^{* 1}$ were not brought before the attention of the judiciary until 2010. The Fifth Criminal Panel found that pre-implantation genetic diagnostics (PGD) are consistent with Section 1(1), no. 2 of the Embryo Protection Act and are therefore not punishable. ${ }^{{ }_{2}}$ The Chamber of the European Court of Human Rights (ECtHR) found against Austria because the intended prohibition of heterologous embryo transfer following ovum donation and the prohibition of sperm donation under Austrian law would constitute discriminatory treatment ${ }^{*}$; this ruling was overturned by the Grand Chamber of the European Court of Human Rights in a subsequent judgment. ${ }^{*}$ Even though the case turned out to be a lot of fuss about nothing, both the prohibition on ovum donation and that on surrogacy were thrown into question. ${ }^{*} 5$

However, the judgment came as a surprise to many, since the medical community had not been offering pre-implantation genetic diagnostics, on account of great uncertainty about the interpretation of the Embryo Protection Act and the associated risk of criminal prosecution. Some considered it to have been excluded entirely. This was probably also the view taken by the legislature, since Section 15 of the new

1 On bioethics as a part of medical and health law, see Rosenau, Reproduktives und theraupeutisches Klonen, in: Amelung et al. (Publ.), Festschrift Schreiber, Heidelberg 2003, p. 761; Albers, Bioethik, Biopolitik, Biorecht: Grundlagen und Schlüsselprobleme, in: Albers (Publ.), Bioethik, Biorecht, Biopolitik, 2016, p. 9 (17ff.). - DOI: https://doi.org/10.5771/9783845275734-9. For a more sceptical view, see Schreiber, Biomedizin und Biorecht, in: Lilie/Bernat/Rosenau (Publ.), Standardisierung in der Medizin als Rechtsproblem, Baden-Baden 2009, p. 11 ff. - DOI: https://doi.org/10.5771/9783845215020-9.

2 German Federal Court of Justice (BGH), judgment dated 6 July 2010 - 5 StR 386/09, NJW 2010, 2672 ff. On the same issue, see Schroth, Forschung mit embryonalen Stammzellen und Präimplantationsdiagnostik im Lichte des Rechts, JZ 2002 170 (174); Günther, in: Günther et al., Embryonenschutzgesetz, Stuttgart 2008, Section 1(1), no. 2, marginal no. 21 for more detail; on the judgment itself, see Merkel, Lebensrecht und Gentest schließen sich aus, Die Zeit, 3rd of August 2010; Dederer, Zur Straflosigkeit der Präimplantationsdiagnostik, MedR 2010, 819ff. - DOI: https://doi.org/10.1007/s00350-0102800-4; Schumann, Präimplantationsdiagnostik auf der Grundlage von Richterrecht?, MedR 2010, 848 ff. - DOI: https:// doi.org/10.1007/s00350-010-2806-y.

3 European Court of Human Rights (ECtHR), judgment dated 1 April 2010 - S.H. and Others v. Austria - no. 57813/2000, RdM 2010, $85 f f$. See also the comment by Bernat, RdM 2010, 88 ff.

4 ECtHR (GC), judgment of 3 November 2011 - S.H. and Others v. Austria - no. 57813/2000.

5 Bernat (note 3), 90. For Switzerland, see Rütsche/Wildhaber, note on judgment of the ECtHR (note 3), AJP 2010, 803 (806f.). 
Genetic Diagnosis Act (GenDG) of 31 July $2009^{* 6}$ addressed only prenatal diagnosis, as PGD had evidently been dealt with adequately in the Embryo Protection Act. In any case, public debate ensued that resulted in the new Section 3a of the Embryo Protection Act restricting application of pre-implantation genetic diagnostics also in Germany. ${ }^{*} 7$

This showed that the German Embryo Protection Act, dating from $1990^{* 8}$, is no longer up-to-date and is in need of reform, and that this need for reform extends far beyond just individual-level ethics questions. ${ }^{*}{ }^{*}$ Reference has already been made to the impulses provoked by the decisions of the European Court of Human Rights. The need for reform is due to the rapid rate of developments in reproductive medicine, which have gone far beyond the terminology and rules contained in the Embryo Protection Act. The latter is also technological law, which carries an obligation to be updated to keep up with developments. It should be recognised that the Embryo Protection Act is also subject to the strict prohibition, pursuant to Article 103(2) of the Basic Law for the Federal Republic of Germany (GG), of an act being punished without it having previously been defined as a criminal offence (nulla poena sine lege). At the time the Embryo Protection Act was passed, in 1990, there was no federal legislative competence for reproductive medicine within the German Federal System, ${ }^{*} 10$ and said act had to be based on general legislative powers governing criminal law (Article 74(1), no. 1 of the Basic Law) and drawn up as a purely criminal statute.

Germany needs to have a modern and up-to-date law covering reproductive medicine, ${ }^{* 11}$ in order to keep pace with the legislative reforms in neighbouring countries such as Austria and Switzerland. It is time for the German legislature to overcome its reservations about reforming the law in the area of bioethics. ${ }^{*}{ }^{12}$ In the words of the great medical ethics lawyer Adolf Laufs: "We have been waiting for a law on reproductive medicine for a long time." ${ }^{* 13}$

A working group of medical ethics lawyers from Augsburg and Munich has taken up this challenge. Its proposal for a law on reproductive medicine (AME-FMedG) constitutes a comprehensive and up-to-date set of rules governing the whole field of reproductive medicine. ${ }^{*} 14$

The draft law also covers ovum donation and surrogacy. We consider both ovum donation and surrogacy to be permissible, provided that certain conditions are met. The provision governing ovum donation is formulated as follows, but please note that subsection 5 , which is printed in italics, is not supported by all members of the working group.

\section{Section 6 Ovum donation ${ }^{* 15}$}

(1) The ova of a third person may be used for medically supported fertility treatment where a woman is infertile, or where the use of the woman's own ovum carries a risk of the child to be conceived having a severe genetic illness.

$6 \quad$ Federal Law Gazette (BGBl.) 2009 I, 2529 ff.

7 On the basis of the Pre-Implantation Genetic Diagnosis Act (PräimpG) of 21 November 2011, BGBl. I, 2228 $f$.

8 Federal Law Gazette (BGBl.) 1990 I, 2746ff.

9 For this, see also the wide-ranging dissertation of Dorneck, Das Recht der Reproduktionsmedizin de lege lata und de lege ferenda, Baden-Baden 2018. - DOI: https://doi.org/10.5771/9783845291246. In the same direction now also argues the Nationale Akademie der Wissenschaften Leopoldina (Publ.), Fortpflanzungsmedizin in Deutschland - für eine zeitgemäße Gesetzgebung, 2019.

10 By statute dated 27 October 1994 (BGBl. I, 3146), the competence powers under Art. 74 I GG were extended in no. 26 to include a specific federal legislative competence for rules governing reproductive medicine, genetic technology, and organ transplantation.

11 See Rosenau (Publ.), Ein zeitgemäßes Fortpflanzungsmedizingesetz für Deutschland, Baden-Baden 2012. - DOI: https:// doi.org/10.5771/9783845244488; Dorneck, Das Recht der Reproduktionsmedizin de lege lata und de lege ferenda, BadenBaden 2018, pp. $390 f$., $393 f$. - DOI: https://doi.org/10.5771/9783845291246; now in the same vein, also a paper of the Leopoldina: Beier et al., Ein Fortpflanzungsmedizingesetz für Deutschland, 2017.

12 Wahl, Das Öffentliche Recht als Fundament und dritte Säule des Medizinrechts, in: Arnold (Publ.), Festschrift Eser, Munich 2005, p. 1243 (1253); Rosenau, Vom Beruf unserer Zeit einer biomedizinischen Gesetzgebung, RdM $2014,290$.

13 Laufs, Ein Spiegeldbild der Ärzteschaft, MedR 2011, 568 (569). - DOI: https://doi.org/10.1007/s00350-011-2983-3.

14 The working group comprises professors Ivo Appel, Ulrich M. Gassner, Jens Kersten, Matthias Krüger, Josef Franz Lindner, Jörg Neuner, Henning Rosenau, and Ulrich Schroth. The main findings of this group are summarised in this paper, and the draft law has been published as follows: Gassner/Kersten/Krüger/Lindner/Rosenau/Schroth, Fortpflanzungsmedizingesetz, Augsburg-Münchner-Entwurf, Tübingen 2013. A critical evaluation of this proposal is given by Dorneck (note 11).

15 Gassner/Kersten/Krüger/Lindner/Rosenau/Schroth, Fortpflanzungsmedizingesetz, Augsburg-Münchner-Entwurf, Tübingen 2013, p. 5 and (with reasons) p. $57 f$. Please note that the text shown is a translation of the original German text of the draft law that is provided for informational purposes. 
(2) Medically supported fertility treatment using the ova of a third person may only be carried out at a registered centre for fertility treatment.

(3) Before donated ova may be used for medically supported fertility treatment, the third person and the ova she has donated must be examined. This examination must ascertain whether, as indicated by current scientific knowledge, the donated ova are viable for use in reproductive medicine and their use would not entail any recognisable health risk for either the recipient of the ova or the child to be conceived.

(4) Only ova all of the same donor may be used during a round of medically supported fertility treatment.

(5) A third person may only donate ova for the purposes of medically supported fertility treatment to one registered fertility centre, and these ova may only be used for fertility treatment for a maximum of three donees.

(6) The donation of ova for medically supported fertility treatment may not be made on the basis of a legal agreement involving remuneration. The registered fertility centre may reimburse the donor for expenses.

Surrogacy is covered by Section 8 of the draft law (AME-FMedG):

\section{Section 8 Surrogacy ${ }^{*} 16$}

(1) Surrogacy may only take place where there is a notarised agreement confirming the unconditional and irrevocable acceptance of the child by the third party, and where the notary has previously instructed the parties on the civil law consequences of a surrogacy agreement, particularly with respect to family and inheritance law. Sections 18 and 21 remain unaffected.

(2) Medically supported fertility treatment by way of surrogacy may only be carried out at a registered centre for fertility treatment.

(3) Surrogacy may not be carried out on the basis of a remuneration-entailing legal agreement. Reimbursement for expenses and a fee for medically supported fertility treatment are permitted.

What has happened to cause us to embrace these modern procedures and include them in our concept of a model law on reproductive medicine? For this, I need to address issues of human rights and constitutional law. Is there a constitutional right to reproduction that overrides the individual decisions made by the national legislature, and what would be the extent of such a right? I address this issue in the first part of the paper. We must also bear in mind the issue of whether constitutionally anchored protections in the Basic Law of Germany (GG) can restrict certain techniques developed by reproductive medicine. The wish to have children is addressed in this context.

Finally, the legal and political reasons for and arguments against the permissibility of ovum donation and surrogacy presuppose that there is a constitutional requirement for a process to be either allowed or prohibited. It is to be expected that the national legislature will seek to retain some discretion or margin of appreciation with respect to biomedical ethics issues. ${ }^{*}{ }^{*}$ Legislating in the area of biomedical ethics is not mere constitutional enforcement. Where the legislature regulates individuals' fertility treatments, it needs to balance conflicting and constitutionally relevant interests.

16 Gassner/Kersten/Krüger/Lindner/Rosenau/Schroth, Fortpflanzungsmedizingesetz, Augsburg-Münchner-Entwurf, Tübingen 2013, p. $6 f$. and (with reasons) p. $61 f$. Please note that the text shown is a translation of the original German text of the draft law that is provided for informational purposes.

17 See Rosenau (note 1), Festschrift Hans-Ludwig Schreiber, Heidelberg, 761 (781); Heun, Embryonenforschung und Verfassung - Lebensrecht und Menschenwürde des Embryos, JZ 2002, 517 (523f.). 


\section{Constitutional law and reproductive medicine}

\subsection{The constitutional legal position}

The constitutional analysis follows a rule-exception method.

The basic assumption starts with the freedom of choice. Normative realisation of an interest is the rule; non-realisation is the exception. In principle, all interests derived from basic constitutional rights, special personal freedoms, or general freedoms (Article 2(1) of the Basic Law) are constitutionally protected.

However, the provisions of the Basic Law do not afford absolute protection to a substantive self-determined interest or realisation of that interest - such as a specific biomedical process - and instead they are subject to the reservation of the principle of constitutional restriction. But restriction of constitutionality as an exception to a rule requires justification, and such justification can itself only be valid if it is constitutional. This assessment, which is directly binding for the legislature pursuant to Article 1(3) of the Basic Law, must be considered by the legislature before it passes any law that restricts constitutional rights. The legislature bears the normative burden of reasoning.

\subsection{European law}

In addition to the Basic Law, before formulating its own laws the German legislature must take account of relevant bioethics laws passed within the European framework. Different regulations have been passed by the European Union (EU) and under the European Convention on Human Rights (ECHR).

\section{a) EU law}

The EU treaties (Treaty on the European Union, or TEU, and Treaty on the Functioning of the European Union, TFEU) do not themselves contain any direct policies on bioethics. The EU also does not have exclusive legislative competence for biomedicine (Article 2(1) of the TFEU in conjunction with Article 3), so there are no restrictions on the competence of the German legislature to pass national regulations on such matters. As it has no competence in this area, the EU does not have competence to regulate medical law by way of EU secondary legislation. Article 168 of the TFEU does give the EU competence in the area of public health, but this does not include biomedicine. Article 168(5) of the TFEU also excludes 'any harmonisation of the laws and regulations of the Member States'. For this reason, there is almost no EU secondary legislation pertaining to biomedicine that needs to be taken into account and followed by national legislatures when they are determining regulations on ovum donation or surrogacy.

Nor is the Charter of Fundamental Rights of the EU binding for legislatures of the Member States in the area of biomedicine. Article 3(2) of the Charter does refer to basic rights in the areas of 'medicine' and 'biology': for informed consent, the prohibition of eugenics practices, prohibition of making the human body a source of financial gain, and prohibition of the reproductive cloning of human beings. But, pursuant to Article 51(1), sentence 1 of the Charter of Fundamental Rights of the EU, this applies to Member States 'only when they are implementing Union law'. So specifications in German laws on biomedicine are not merely an implementation of EU law, because EU law does not contain any specific provisions in this regard.

This is not the case with EU fundamental rights. As must every other law passed by Member States, the provisions of national biomedical laws must be in line with $\mathrm{EU}$ fundamental rights. The first right is the freedom to provide services (Article 56 TFEU), which may be infringed by restrictive rules applying to the operators of biomedical facilities (such as fertility centres).

\section{b) The European Convention on Human Rights (ECHR)}

In the Federal Republic of Germany, as a convention under international law the European Convention on Human Rights has the same internal status as a law promulgated by the Federal Republic (under Article 59(2) of the Basic Law). The federal legislature is not directly bound by the Convention. However, the fundamental rights under the Convention must be taken into consideration when one is interpreting constitutional rights under the Basic Law. Also, the Federal Republic of Germany is bound to observe the 
Convention under international law, and each national law is to be measured against the provisions of the Convention. However, the directive effect of the Convention for the national legislature in the area of biomedical ethics is limited. It is subject to neither a restrictive nor a liberal approach.

Compatibility of national regulations with the European Convention on Human Rights does not mean these will necessarily also be compatible with the corresponding constitutions of the Member States - in the case of Germany, with the Basic Law. This is because the Convention affords only a minimal level of protection of fundamental rights, which may be exceeded by the constitutions of the individual High Contracting Parties (Article 53 of the ECHR). This means that, even if it meets the requirements of the European Convention, a German law on biomedical ethics will not necessarily be constitutional under German law. Moreover, with the multi-level system of fundamental rights in Europe, it may be that a rule is compatible with the European Convention on Human Rights but simultaneously unconstitutional from a national perspective.

\section{c) The Convention on Human Rights and Biomedicine of the Council of Europe}

The Convention on Human Rights and Biomedicine of the Council of Europe, which also contains provisions relevant for biomedicine (e.g., on intervention in the human genome (Article 13) and research on embryos in vitro (Article 18)), has not been ratified by Germany. Therefore, it has no force in Germany under international law.

\subsection{Consequences for reproductive medicine}

The rule says that the interests of the prospective parents in having children by using their own or donated cells, of the sperm or ovum donors, and the interests of the helpers (fertility centres and surrogate mothers) - i.e., of all interested parties that are or may become relevant in the area of reproductive medicine - all proceed from the presumption that the interests will be permissible. This presumption in favour of freedom plays an important role in the debate about reproductive medicine: It allows all relevant interests to be considered in assessment of the constitutional arguments - and does not allow them to be prematurely excluded on ethical or religious grounds or in regard of other preferences.

The exception says that the restriction of realisability of an interest - such as prohibition of ovum donation or surrogacy under applicable law - is only permissible if it can be justified on constitutional grounds. This justification must satisfy strict standards of rationality.

\section{a) The right to have children (reproductive self-determination)}

Parents who wish to have children are supported by general human rights when reproduction rights are being formulated. The general personal human right incorporated via Article 1(1) in conjunction with Article 2(1) of the Basic Law has been developed by the Federal Constitutional Court in Germany (BVerfG) and expanded upon in many, quite different cases to include a broad spectrum of personal integrity and development of human interests. Today, differentiation is made among rights of self-determination, selfpreservation, and self-projection. The right to decide positively or negatively over your own reproduction, as well as the possibility and method of reproduction, is regarded as a right of self-determination. One may refer to a 'fundamental human right of reproductive self-determination'. The right to have a child of one's own is one of the core components of personal identity and identity-building. It is an integral component of general personal human rights protected under Article 1(1) in conjunction with Article 2(1) of the Basic Law, and it may be restricted only so as to protect outstandingly important legal interests. Also, it would be worth debating whether a basic human right to reproduction or reproductive self-determination would not be better anchored in Article 6(1) of the Basic Law (on protection of marriage and children) than under Article 1(1) in conjunction with Article 2(1). However, it is not necessary to develop this argument further, as in the end it is not relevant which underlying fundamental right is used to protect the norm. That said, the proximity to human dignity however, would suggest that the fundamental human right to reproduction is better anchored in Article 1(1) in conjunction with Article 2(1). 


\section{b) The scope of protection}

The basic human right to reproduction or reproductive self-determination is of both a personal and a factual nature. From a personal perspective, all people have a fundamental human right to reproduction, whether they be married or unmarried couples, same-sex couples, or individuals who wish to have a child but not within the scope of a partnership. From a factual perspective, the protection covers not only natural procreation but also medically assisted reproduction. This includes all methods possible under current scientific knowledge: artificial insemination, gamete transfer, ovum and semen donation, in vitro fertilisation (IVF), and intracytoplasmic sperm injection (ICSI). This list is by no means complete. The fundamental human right to reproductive self-determination is open to development: any possible or future measure that will be medically supported is subject to the presumption of permissibility. This includes morphologic examination of the in vitro embryos to determine the viability of said embryos, and the transplantation of only those embryos that are viable. Single or double embryo transfers as part of IVF are also protected in principle meaning the transplantation of the embryo that seems most viable. This allows for avoidance of potentially dangerous multifoetus pregnancies.

The use of semen and ovum donations or surrogacy is also covered by the fundamental human right of reproductive self-determination. However, the potential donee has no right to receive a semen or ovum donation from a third party, because the fundamental human right to reproductive self-determination does not have an indirect third-party effect between subjects in private law. Nonetheless, the fundamental rights can be used as a defensive mechanism against the State to ensure use of the donated cells if the donation has been made voluntarily by a third person. The current state ban on ovum donation therefore constitutes an (unjustified) breach of the fundamental human rights of couples who wish to have a child but wherein the woman is infertile.

As with all fundamental human rights, the negative side of reproductive self-determination too is protected - this means the right not to use reproductive fertility assistance. The legislature must introduce protective measures to ensure the provision of information and consent, and the prohibition of the use of gametes without the permission of the donor, or reproduction determined by a third party.

\section{c) Restrictability}

As is every fundamental right, the fundamental human right to reproductive self-determination does not include any unrestricted or unrestrictable protection of interests. The legislature may envisage restrictions to protect constitutionally protected legal interests but must adhere to strict rationality requirements. In particular, this includes an assessment of proportionality. (1) Any restriction on the fundamental human right to reproduction must have a constitutionally legitimate purpose, (2) there must be a need to meet a specified purpose, (3) the intervention must be suitable for realising the purpose, (4) it must be necessary, and (5) the purpose and intervention must be proportionate to each other. The more onerous the intervention - in particular, with respect to criminal liability - the higher the requirements for justification. This results in the following situation with respect to reproductive medicine:

The fundamental human right to reproduction is a right of human dignity, because reproduction affects on personal integrity and continuance of dignity over and above one's own existence. Therefore, there must be special requirements with regard to any legal interests that need to be protected by potential restrictions on the fundamental human right to reproductive self-determination. Reasonable consideration of the common good will not suffice in this respect. Any such legal interests should also have constitutional weight and include an element of human dignity; among these are the life and health of the mother, the health of the child to be conceived, and the interests of the child in being aware of its heritage.

Even if a weighty protection interest can be invoked, there should also be special requirements related to proportionality, especially concerning the balancing of interests. Such balancing should not be just of an abstract nature: it should be a thought-specific balancing. We need to address also whether a general and absolute prohibition (such as that of ovum donation or surrogacy) is also justified in special individual circumstances. Generalised consideration of a legal interest, such as the wellbeing of the child, is not sufficient here. Particular attention must be paid also to there being a need to fulfil a purpose. The legislature must consider the following: Is the wellbeing of the child at all affected by a certain technical reproductive measure? 
The balancing of interests ${ }^{*} 18$ should also indicate a balanced outcome. This means that neither the interests of the parties nor the legal interests to be protected should be fully repressed. Under the legal doctrine of fundamental rights, this is denoted as the principle of practical concordance. It creates a balance between conflicting rights and legal interests by which the norms are to be seen in the context of other provisions and limits are imposed on conflicting interests such that both can achieve optimal effectiveness. ${ }^{*}{ }^{19}$

\section{d) Discussion at the level of European human rights: the European Convention on Human Rights}

There has been debate as to whether a prohibition of ovum donation has a human rights dimension, and this debate has even reached the European Court of Human Rights (ECtHR). In the case of S.H. and Others $v$. Austria, the Chamber of the Court found against Austria, which had prohibited the use of donated sperm in IVF and heterologous embryo transfer after ovum donation (Section 3(1) and (3) of the Austrian Artificial Procreation Act - öFMedG). The Austrian Constitutional Court (VfGH) had previously recognised that the decision to conceive a child, and to use modern reproductive medicine methods in order to achieve that goal, falls under the right to respect for one's private life pursuant to Article 8 of the European Convention on Human Rights. Moreover, prohibition by way of citing the limitations set out under Article 8(2) of the Convention was legitimate and also proportionate. ${ }^{{ }^{20}}$

However, the Chamber of the European Court of Human Rights found that there had been a violation of the prohibition on discrimination with respect to one's private life (Article 14 in conjunction with Article 8 of the European Convention on Human Rights). The Chamber found no reasonable justification for the unequal treatment of couples who required donated ova in order for their fertility treatment to be successful, as compared to couples who also made use of fertility treatment in order to fulfil their desire to conceive a child but who were able to use their own ovum. ${ }^{* 21}$ The same applies for the prohibition of IVF where the sperm were donated.

This judgment did not stand for long, as the Austrian government applied for the matter to be referred to the Grand Chamber of the European Court of Human Rights and was supported in the application by Germany. The 17 judges in the Grand Chamber reversed the judgment of the lower court. ${ }^{* 2}$ The Grand Chamber made reference to the substantial margin of appreciation given to individual states when they consider whether interference in the right to a private life pursuant to Article 8(2) of the European Convention on Human Rights is necessary - in effect, whether the reasons to protect health or morals or to protect the rights and freedoms of others appear to be justified. This margin of appreciation becomes wider as the societal and legal evaluation of the issue diverges among the 47 Member States of the Council of Europe. This is certainly the case with respect to the issues of ovum donation and surrogacy. The Grand Chamber even stated that Austria had tried not to prohibit heterologous embryo transfer or ovum donation, but it then admitted that the decision is in effect a political decision that could go either way as it does not exceed the margin of appreciation granted to individual states. ${ }^{* 3}$

In its judgment, the Grand Chamber accepted the Austrian legal position but restricted the applicability of the judgment by saying that it only addressed the legal position in 1999 and was an effective retrospective assessment of the legal position at that time. The Court did not address whether the legal position would be regarded as justifiable today under Article 8 of the European Convention on Human Rights. ${ }^{*}$ In the meantime, after all, something has changed in Austria as well. There is talk of a far-reaching change. ${ }^{*}{ }^{25}$ The

18 BVerfGE 35, 202 (225).

19 Hesse, Grundzüge des Verfassungsrechts der Bundesrepublik Deutschland, 20th Ed. 1995, p. 28.

20 VfGH, MedR 2000, 389 with comment by Bernat.

21 EGMR, RdM 2010, 85 with comment by Bernat.

22 EGMR, Familien- und Erbrecht (EF-Z) 2012, 24 with comment by Bernat. See also Bernat, Österreichischen Fortpflanzungsmedizingesetz auf dem Prüfstand des Europäischen Gerichtshofs für Menschenrechte, Der Gynäkologe 2012, 331 ff. - DOI: https://doi.org/10.1007/s00129-012-2949-1.

23 EGMR, Familien- und Erbrecht (EF-Z) 2012, 24 (25).

24 Bernat, in: Rosenau (Publ.), Ein zeitgemäßes Fortpflanzungsmedizingesetz für Deutschland, 2012, p. 203 (212). - DOI: https://doi.org/10.5771/9783845244488-203.

25 Bernat, Das österreichische Abstammungsrecht im Kontext der medizinisch unterstützten Fortpflanzung. Eine Bestandsaufnahme nach Inkrafttreten des Fortpflanzungsmedizin-Änderungsgesetzes 2015, in: Schurr/Umlauft (Publ.), Festschrift für Bernhard Eccer, Wien 2017, p. 43 (50). 
Supreme Court of Justice in Austria (OGH) has considered a similar issue in two further judgments. It has referred the prohibition of reproductive medicine methods in surrogacy for two women ${ }^{* 26}$ and of artificial insemination in same-sex partnerships ${ }^{* 27}$ to the Austrian Constitutional Court, because the Supreme Court considers these prohibitions to violate human rights under Article 8 of the European Convention on Human Rights. And, not ten years later, the Austrian Constitutional Court agreed with the Supreme Court, and, among other provisions, on 10 December 2013 it declared Section 3(1) and (2) of the Artificial Procreation Act (öFMedG) to be unconstitutional. ${ }^{*} 28$ There has been liberalisation with regard to same-sex partnerships, now also in the law. ${ }^{* 29}$ Surrogate motherhood continues to be banned in Austria, ${ }^{*}{ }^{30}$ but here too the courts raise the question of whether foreign decisions are to be recognised, decisions according to which the child born of the surrogate mother is to be assigned to the Austrian wish parents. ${ }^{*}{ }^{31}$

For the purposes of our discussion, it should be noted that the modern methods of reproductive medicine fall under the right to a private life, which is protected by Article 8 of the European Convention on Human Rights. Notwithstanding some fluctuation in arguments, this approach has in essence not been questioned in any of the decisions.

But what does this mean in concrete terms for ovum donation and surrogacy?

\subsection{Ovum donation and surrogacy}

\section{a) Prohibition of ovum donation}

The current position under German law is that ovum donation - unlike semen donation - is prohibited for fertility treatment purposes. The current prohibition is derived from Section 1(1), no. 1 of the Embryo Protection Act (ESchG). The Embryo Protection Act presumes a general prohibition of divided maternal rights, and it avoids any potential conflict between the biological donor and the woman carrying the child. This constitutes an intervention in the rights of parents to conceive a child by means of a donated ovum. The wellbeing of the child is taken as overall legal justification for this approach. A child, upon having discovered that the mother who carried him or her to term was not the biological mother, could suffer psychological problems or problems in finding his or her own identity. ${ }^{* 2}$ This is an assumption that thus far has not been proved empirically. Instead, perhaps the assessment should consider that without the ovum donation there would have been no child, by which one enters into an existential circular argument. Another matter to be considered is that the child was desired by the parents and receives their love and attention, and that this should be assessed in a positive way with respect to the psychological wellbeing of the child. Reference to the wellbeing of the child should not be employed as justification for prohibiting ovum donation. ${ }^{*} 3$

It cannot be seriously argued, at least in a convincing manner, that an ovum donation by a woman violates the human rights of the donor while a semen donation by a man does not. The difference cannot be put down to the higher costs of the former procedure and more invasive intervention. There can be no discussion of a violation of dignity when the woman decides to make a donation after full consultation, voluntarily and without any infringement of her autonomy. Full legal information obligations are certainly necessary, but not complete prohibition of the ovum donation. Commercialisation of the process, however, should be avoided, and markets must not be allowed to develop, ${ }^{*} 34$ as it would then be all too easy for the voluntary nature of the donation to be called into question. In light of all this, from a constitutional point of view the

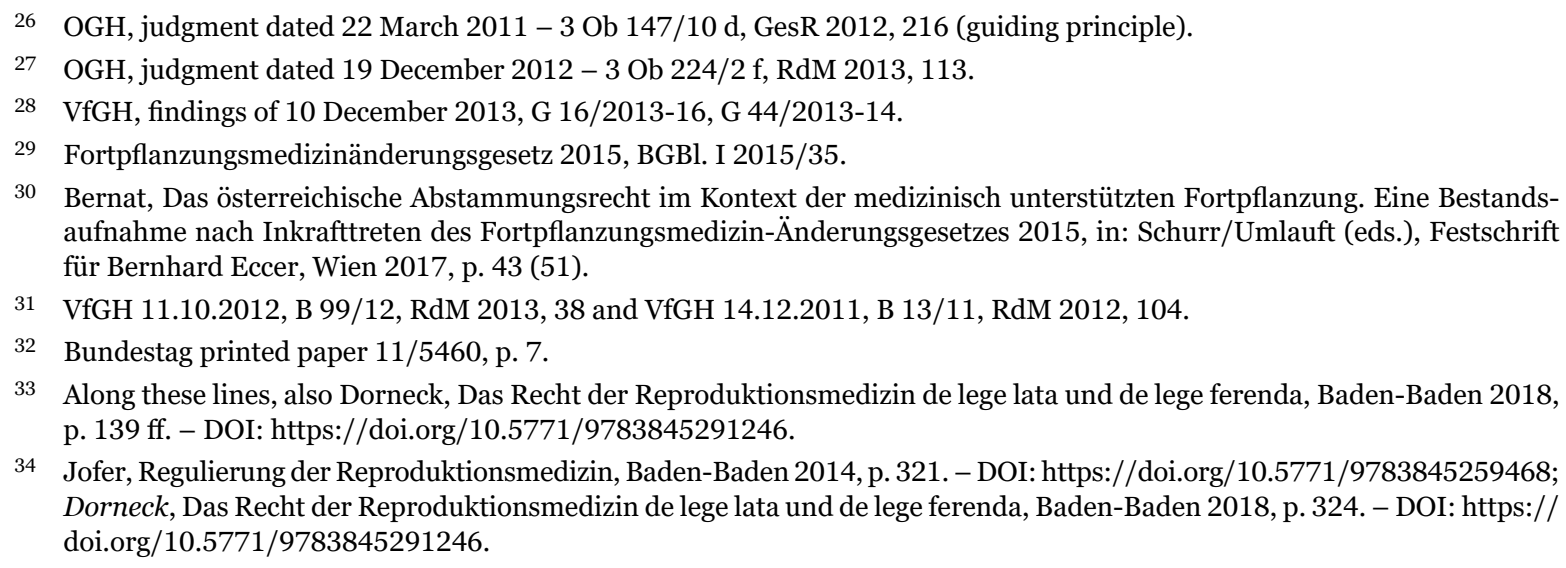

33 Along these lines, also Dorneck, Das Recht der Reproduktionsmedizin de lege lata und de lege ferenda, Baden-Baden 2018, p. 139 ff. - DOI: https://doi.org/10.5771/9783845291246.

34 Jofer, Regulierung der Reproduktionsmedizin, Baden-Baden 2014, p. 321. - DOI: https://doi.org/10.5771/9783845259468; Dorneck, Das Recht der Reproduktionsmedizin de lege lata und de lege ferenda, Baden-Baden 2018, p. 324. - DOI: https:// doi.org/10.5771/9783845291246. 
prohibition of ovum donation is not sustainable. However, partial restrictions on ovum donation - such as ones to protect ovum donors from health dangers or exploitation - could be considered. These could be supported by examination and information obligations, and by restrictions on performing ovum donation for a fee.

\section{b) Prohibiting surrogacy}

\section{(1) Debate about surrogacy}

What applies to ovum donation also applies to surrogacy. A surrogate mother is a woman who is prepared to undergo a medically supported reproduction procedure in order for her to hand over the child, after birth, to be raised by a third party. This definition is based on Section 13a of the German Adoption Placement Act (AdVermiG). That statute uses the term 'Ersatzmutter' (replacement mother), whereas the term 'Leihmutter' (surrogate mother) has become accepted in common usage.

Surrogacy is also penalised under the current state of the law by Section 1(1), no. 7 of the Embryo Protection Act (ESchG). Once again, the justification for this position is connected with the protection of various legal interests. ${ }^{*} 35$ In the interest of the wellbeing of the child, there should be no division of maternal rights, as this would make it more difficult for the child to find a personal identity, it could cause psychological conflicts, and the child would be reduced to the status of a traded product. Possible legal disputes between various parents could also affect the wellbeing of the child. The following problems are conceivable: the genetic parents may decide during the course of the pregnancy that they no longer wish to have the child, because a prenatal diagnosis (which cannot even be demanded from the surrogate mother) determines that the child has a disability. Or the genetic parents might die, separate, or merely withdraw from the agreement without giving a reason. In a reverse situation, the surrogate mother could decide to keep the child for herself.

Reference is made also to the human rights of the surrogate mother, who is reduced to the status of a brood mare or birth machine (the right of dignity as against oneself). Another argument is that surrogacy should be non-permitted to protect the institution of marriage and the family of the surrogate mother.

But these arguments are speculative. There are no significant empirical studies that demonstrate a burden on children who grow up in circumstances where maternal rights are divided. ${ }^{*} 36$ Quite the contrary: numerous studies show no alarming results with respect to damage to the wellbeing of children in such situations. ${ }^{*} 7$ If - as is currently asserted sometimes - a secure prenatal relationship and bonding with the child in the womb and corresponding prenatal experiences are necessary for strong subsequent development, then there is no valid scientific evidence to back up this assertion. ${ }^{*}{ }^{8}$ Statements by individual doctors cannot be sufficient to justify intervention in the right to reproduction. ${ }^{*}{ }^{39}$ Significantly, in this debate a division of paternal rights is seen as less problematic with respect to the wellbeing of the child than a division of maternal rights. That is an implausible differentiation that throws a critical light on the validity of this argument.

It may be that these considerations apply in some circumstances but not in all circumstances without exception. Everything depends on the individual circumstances: for example, it may be that a married couple are only unable to conceive a child by natural methods or by using reproductive medical methods because the woman (who has healthy ova of her own) is unable to carry a child to term. A good friend who lives in a stable social environment and has an emotional connection to the parents could declare herself prepared to carry the child for the parents. To prohibit this form of surrogacy would not be justifiable from a constitutional perspective with regard to the weight given to the fundamental human right of reproductive self-determination for couples, and the fact that the parents of the child in this case would be the same

35 Bundestag printed paper $11 / 5460$, p. 8.

36 Schumann, in: Rosenau (eds.), Ein zeitgemäßes Fortpflanzungsmedizingesetz für Deutschland, 2012, p. 155 (186). - DOI: https://doi.org/10.5771/9783845244488-153; Jofer, Regulierung der Reproduktionsmedizin, Baden-Baden 2014, p. 315. DOI: https://doi.org/10.5771/9783845259468; Dorneck, Das Recht der Reproduktionsmedizin de lege lata und de lege ferenda, Baden-Baden 2018, p. 162. - DOI: https://doi.org/10.5771/9783845291246.

37 Constitutional Court (VfGH), findings of 10 December 2013, G 16/2013-16, G 44/2013-14, marginal note 46.

38 Doubts raised by Jofer, Regulierung der Reproduktionsmedizin, Baden-Baden 2014, p. 318 f. - DOI: https://doi. org/10.5771/9783845259468.

39 For another view, see Jofer, Regulierung der Reproduktionsmedizin, Baden-Baden 2014, p. 318 f. - DOI: https://doi. org/10.5771/9783845259468. 
people as the genetic parents (who provide the ovum and sperm). Such a prohibition would not be proportionate. A parent-child relationship that is derived not from nature but from legal agreement has long been accepted in the form of adoption. ${ }^{*} 40$

As adoption does, surrogate motherhood brings in a wide range of complex family law questions. However, these problems have been around for hundreds of years with respect to adopted children, fostered children, and stepchildren, and solutions have always been found for such problems. ${ }^{*}{ }^{41}$

\section{(2) Limits of surrogacy}

In order to take proper account of the constitutionally relevant wellbeing of the child within the meaning of the principle of practical concordance, limits should be set out within which surrogacy may take place: it must be ensured that the child does not become a ping pong ball bouncing between the mothers in the event of any dispute or conflict. One limiting precondition could be that there be a close relationship between the parents and the proposed surrogate mother. On the other hand, it may be that such relationship situations are more likely to cause conflicts to arise than would otherwise be the case. ${ }^{*} 42$

Such potential conflict, which would cause the child to suffer, must therefore be dealt with in advance of the surrogacy arrangement, by the parents assuming absolute and irrevocable responsibility for the child. This would exclude the possibility of surrogacy that has a 'right of return'. This is important, above all, in situations where the child does not meet the parents' expectations, such as when the child suffers from an congenital defect. Such a legal position would also make it clear to the surrogate mother from the outset that she is not the legal mother of the child. Of course, even a clear irrevocable agreement prior to the surrogacy cannot exclude the possibility of parties to the agreement changing their minds, and the irrevocability with its substantive legal effect cannot prevent parties from seeking assistance from the courts. However, it makes the likely decision of the court quite clear. ${ }^{*} 43$

Additionally, a comprehensive statement of the legal consequences of surrogacy is necessary. This is justified because the personal, the emotional, the social, and therefore also the legal consequences of surrogacy extend much further than a mere gamete donation or embryo transfer. There are strong arguments not just in favour of medical information being provided but also for the agreement being notarised after the legal consequences have been explained to the parties.

40 EGMR, RdM 2010, 85 with comment by Bernat.

41 Schumann, in: Rosenau (eds.), Ein zeitgemäßes Fortpflanzungsmedizingesetz für Deutschland, 2012, p. 155 (195; 201). DOI: https://doi.org/10.5771/9783845244488; Dorneck, Das Recht der Reproduktionsmedizin de lege lata und de lege ferenda, Baden-Baden 2018, p. $163 f$. - DOI: https://doi.org/10.5771/9783845291246.

42 Cf. Dorneck, Das Recht der Reproduktionsmedizin de lege lata und de lege ferenda, Baden-Baden 2018, p. $342 f$. - DOI: https://doi.org/10.5771/9783845291246.

43 Critical view: Dorneck, Das Recht der Reproduktionsmedizin de lege lata und de lege ferenda, Baden-Baden 2018, p. 338 ff. - DOI: https://doi.org/10.5771/9783845291246. 